\title{
Can Creative Reinterpretation Keep Operetta Alive? Kálmán's Die Herzogin von Chicago at the Vienna Volksoper in 2004
}

\author{
Lisa FeurzeIG \\ Grand Valley State University \\ 1 Campus Drive \\ Allendale, MI 49401-9403, USA \\ E-mail: feurzeil@gvsu.edu
}

(Received: March 2016; accepted: June 2016)

\begin{abstract}
Kálmán's 1928 operetta Die Herzogin von Chicago reemerged in the 1990s after decades of oblivion. Productions of this work can reveal much about topics such as the relationship of Central Europe and America and attitudes toward outsider groups, both in the 1920s and in more recent times. This study of the 2004 production at the Vienna Volksoper uses interviews to explore the work's political and social meanings for Austrian audiences. It also examines the changes made in this production, which was adapted from the original by Stefan Frey and Dominik Wilgenbus, examines the question of what is "true operetta style," and considers recent operetta reception in Vienna, with attention to the very different responses of the audience and the critics.
\end{abstract}

Keywords: Imre Kálmán, operetta, Die Herzogin von Chicago, Wiener Volksoper

Following on the smashing international success of Ernst Krenek's opera Jonny spielt auf in 1927, composer Imre (Emmerich) Kálmán, with librettists Julius Brammer and Alfred Grünwald, created the operetta Die Herzogin von Chicago (The Duchess of Chicago), which premiered in Vienna on 5 April 1928. Like Jonny spielt auf, this work addressed the encounter of European music with American jazz. The tone shifted as this topic moved into the lighter operetta genre, but nevertheless, the work epitomized important conflicts of the 1920s through fiery exchanges between American sausage heiress Miss Mary Lloyd and European blue-blood Prince Sándor Boris of Sylvaria - who even referred to Jonny spielt auf in one passage. While the sounds of jazz were alluring, their fascinating rhythm did not mask the tensions brought about by American cultural imperialism, threats to European traditions, and shifting economic power in a culture grappling with modernization. 
Die Herzogin von Chicago found immediate success: it had a run of 242 performances in Vienna, and there were also numerous productions in Central Europe and Scandinavia (Berlin, Stockholm, Prague, Budapest, Tre [in Finland], Milan, and Warsaw) in 1928 and 1929. An American version - directed by Busby Berkeley, of all people - did not make it to Broadway. ${ }^{1}$ After this flurry of success, the work was one of those the Nazis labeled in 1938 as entartete Musik (degenerate music), and it went into oblivion for several decades. A 1998 Decca recording, conducted by Richard Bonynge as part of a series devoted to works banned by the Nazis, helped to raise the work's profile, and the operetta attracted renewed attention, receiving many staged performances from the 1990s to 2004 (in Milan, New York, Chicago, Trieste, Dresden, Augsburg, and Philadelphia). The work's return in 2004 to its home city of Vienna in a production at the Volksoper, as part of an Entartete Musik series organized by dramaturge Birgit Meyer, is the focus of this essay. My work is based primarily on the DVD of that production and on interviews I conducted in 2009 with several people connected with it (performers, directors, and adapters) and with Austrian intellectuals who commented on the Austrian political landscape (see Table 1).

TABLE 1 Interviews in 2009

\begin{tabular}{|l|l|l|}
\hline Name & Description & Date and Place \\
\hline Stefan Frey & $\begin{array}{l}\text { Kálmán biographer and one of the two adapters for } \\
\text { the Vienna performance }\end{array}$ & June 5, Munich \\
\hline Dominik Wilgenbus & $\begin{array}{l}\text { Stage director and one of the two adapters for the } \\
\text { Vienna performance }\end{array}$ & June 6, Munich \\
\hline Rudolf Berger & Director of the Volksoper in 2004 & June 9, Vienna \\
\hline Mehrzad Montazeri & $\begin{array}{l}\text { Tenor in the Volksoper company; played Prince } \\
\text { Sándor Boris }\end{array}$ & June 12, Vienna \\
\hline Norine Burgess & $\begin{array}{l}\text { Mezzosoprano; played Miss Mary Lloyd as guest } \\
\text { artist in Vienna }\end{array}$ & August 9, Toronto \\
\hline Erich Neuwirth & $\begin{array}{l}\text { Professor of statistics with focus on Austrian politics } \\
\text { and elections }\end{array}$ & June 2, Vienna \\
\hline Waltraud Heindl & Professor of history & June 4, Vienna \\
\hline Hanna Bubenicek & $\begin{array}{l}\text { Literary scholar and Jungian psychotherapist } \\
\text { June 10, } \\
\text { Oberschützen, } \\
\text { Austria }\end{array}$ \\
\hline Morten Solvik & $\begin{array}{l}\text { Musicologist and director of the Institute for } \\
\text { European Studies, Vienna branch, a study abroad } \\
\text { program for American students }\end{array}$ & June 15, Vienna \\
\hline
\end{tabular}

1. For theater names and dates, see Stefan Frey, "Unter Tränen lachen”: Emmerich Kálmán: Eine Operettenbiografie (Berlin: Henschel, 2003), 349-350. 
In this essay, I explore the evolving political and social meanings of this work in our time, within a world of shifting conditions. Reemerging after decades of oblivion, the Herzogin can serve as a window into important topics such as the relationship between Central Europe and North America and how these regions have viewed "outsiders" such as blacks, Jews, and refugees in the past and the present. It also offers an instructive example of how old works can be creatively restaged so that they remain alive and relevant, rather than being understood as museum pieces firmly anchored in the past. Descriptive analyses of selected scenes demonstrate both the strengths of the original version and also how creative changes in the 2004 version accentuated its ideas.

\section{Die Herzogin in 1928 - context and plot}

Kálmán was tremendously successful as an operetta composer, noted especially for his skill composing Hungarian dances and Gypsy music, which had often been featured in operettas ever since Johann Strauss included a csárdás in Die Fledermaus in 1874 . The Hungarian elements contributed greatly to his success in earlier works such as Die Csárdásfürstin (The Csárdás Princess, 1915) and Gräfin Mariza (Countess Maritza, 1924). By the late 1920s, though, the future of the operetta genre was in question. It was being overtaken by, sometimes blended with, the revue; and American music and dance styles were also invading Europe.

Die Herzogin von Chicago took this bull by the horns by representing the very conflict that threatened operetta. The title character, Miss Mary Lloyd, arrives in Europe, bringing her tremendous wealth and her taste for Charleston, slow-fox, and blues. Her goal is to win a contest held by her club, whose prize goes to the person who purchases what is most rare and difficult to buy. Upon arriving in Budapest, she decides to buy herself a castle and the prince to go with it - specifically, the Prince of Sylvaria. While Prince Sándor Boris finds Mary attractive, he abhors the dance and music that she loves. Nevertheless, because of his kingdom's near bankruptcy, he patriotically allows her to buy his castle, using the money for charitable works for his populace. Eager to make a marriage possible and acquire Mary's money for the kingdom, the Sylvarian authorities arrange to give her a title of nobility by having her declared the "Duchess of Chicago." Just as Sándor and Mary are beginning to express their attraction for each other, he learns about the bet, breaks off their relationship, and announces his engagement to his cousin, Princess Rosemarie. Eventually - no surprises here - the two leading characters are reconciled and plan to wed, each one having meanwhile learned the other's favorite dance. 
Critical response was mixed. ${ }^{2}$ Most critics found the story predictable and similar to earlier works, particularly those from the librettist team of Brammer and Grünwald, and several complained that it was too long for a relatively simple story. The music, though, was captivating and overcame these weaknesses. Most critics agreed that the American-style numbers were most successful:

[...] here it is proven how strong the influence of jazz rhythm is, even on pronounced individualities - for the blues, the Charleston, the slow-fox have been most successful for Kálmán - real international success-music. ${ }^{3}$

He speaks Viennese, Americanese, Waltzese, Charlestonese, he speaks melting, and elegy, speaks elegance, tumult and melancholy, and finally speaks his mother tongue: Hungarian. For him, it is no longer a question of choosing between two- and three-four time; he knows the dosages and mixtures of the perfume, the demagogy of the Gypsy fiddle and that of the saxophone, he knows the hit-loving public that besieges the bands on ocean steamers and in hotel bars on the Riviera and forges his melodies into hits. ${ }^{4}$

On the other hand, another critic observed that "If Kálmán wanted to show that the 'new' music still doesn't triumph over the old, he has succeeded." It was widely agreed that the productions were opulent and exciting, with fine performers to bring out the musical contrasts. The team of Kálmán, Brammer, and Grünwald had created another hit - but after its early success, it disappeared for a long time due to dictatorship, anti-Semitism, and then the turmoil of the World War. What would the work mean to audiences of the early twenty-first century when it resurfaced decades later?

2. Several reviews from the Vienna and Berlin performances are reprinted in Kevin Clarke's book "Im Himmel spielt schon die Jazzband”: Emmerich Kálmán und die transatlantische Operette 1928-1932 (Hamburg: von Bockel, 2007), 484-504. The translations are my own.

3. "[Bei seiner eigenen Musik] erweist es sich hier, wie stark der Einfluß des Jazzrhythmus selbst auf ausgeprägte Individualitäten ist, denn die Blues, die Charleston, die Slow-Fox sind Kálmán am besten gelungen, richtige, international Erfolgsmusik." Ludwig Hirschfeld, "Kálmán Premiere," Neue Freie Presse (6 April 1928), reprinted in Clarke, Emmerich Kálmán, 485.

4. "Er kann Wienerisch, Amerikanisch, Walzerisch, Charlestonisch, er kann Zerfließen, und Elegie, kann Schmiss, Tumult und Melancholie und kann schließlich seine Muttersprache: Ungarisch. Für ihn bildet Zwei- oder Dreivierteltakt keine Frage mehr, er kennt die Dosierungen und Mischungen des Parfüms, die Demagogie der Zigeunergeige wie die des Saxophons, er kennt das Schlagerpublikum, das Schiffskapellen auf Ozeansteamers und Salonkapellen in den Hotelbars der Riviera belagert, und hämmert seine Melodien auf Schlager zu." Ernst Decsey, "Die neue Kálmán-Operette," Neues Wiener Tagblatt (6 April 1928), reprinted in Clarke, Emmerich Kálmán, 495.

5. "Wenn Kálmán zeigen wollte, daß die 'neue'Musik ja doch nicht über die alte triumphiert, so ist ihm das gelungen." Fred Keller, "Die Herzogin von Chicago oder Marischka spielt auf," Der Tag (6 April 1928), reprinted in Clarke, Emmerich Kálmán, 488. 


\section{The 2004 adaptation - circumstances and alterations}

In the 2004-2005 season, the Volksoper, working with the Staatsoper, presented a series of five works that had been declared decadent by the Nazis. With premieres from October through December, the pieces were presented in this order: at the Volksoper, Franz Schreker's Irrelohe, Walter Braunfels' Die Vögel, Alexander Zemlinsky's Der König Kandaules, and Kálmán's Die Herzogin von Chicago, and at the Staatsoper Erich Korngold's Die tote Stadt. The series was preceded by a twoday symposium sponsored by the Volksoper, one major theme being that Nazi cultural policy had succeeded in erasing many such works from the cultural memory. ${ }^{6}$

For this reintroduction, Die Herzogin was presented in an adapted version designed by Dominik Wilgenbus, who also served as stage director, and Stefan Frey, an operetta scholar whose biography of Kálmán had appeared the year before. In our interview, Wilgenbus explained what changes they made and why. Their two main goals were to shorten the original, which had lasted over five hours at the first performance, and to make it flow more effectively. Having since read the libretto from the Regiebuch of the first production, I agree that their changes make the story more clear. In the original, the show opens with a scene in the Grille américaine, a bar in Budapest. Mary Lloyd visits this bar upon her arrival in Budapest, and it is there that she meets Prince Sándor Boris. She also explains the nature of her club's bet during this scene, speaking to the American ambassador so that others do not hear. Her decision to go after the prince as her "purchase" to win the prize evolves slowly after she first meets him.

Wilgenbus and Frey added an opening scene in New York, showing the meeting of the club where the contest is announced: "so that we don't just narrate this, but show it." They moved the Grille américaine confrontation - undoubtedly one of the strongest scenes in the work - so that it falls in the middle of Act I rather than being the prologue to the whole show. They also reorganized other scenes, arranging them so that the location shifts back and forth between the Sylvarian court and the Budapest bar to make the operetta less static. In the process, they noticed that this structure of alternating locations was reminiscent of cross-cutting in a film, so they deliberately added more references to film throughout, as I discuss below.

According to Frey,

Dominik wanted other singers, he wanted a jazz singer for the duchess who sings completely differently, and for Bondy too. He wanted this clear oppo-

6. See Birgit Meyer, "Entartete Musik - wieder entdeckt," David: Jüdische Kulturzeitschrift 63 (2004). David.juden.at /kulturzeitschrift/61-65/63-Meyer.htm (accessed February 2016).

7. Some interviews were in German, some in English, and some in a combination of the two languages. I present all quotations in English; any translation is my own. For details of the people interviewed and dates, see Table $I$. 
sition of singing styles, and then Rosemarie and Sándor as operetta figures [...] I think, if there had been more extremes in the casting, then it would have worked even better.

Wilgenbus also wanted to hire jazz instrumentalists who could engage in real improvisation during the jazz-influenced scenes. Yvonne Kálmán, the composer's daughter, expressed her approval for the change - but the Volksoper direction rejected this idea, both for reasons of cost and because they feared it would not be accepted by the Vienna audience. Wilgenbus argued to me that in the 1920s the type of style mixture he had advocated was normal:

In those days, obviously, it was possible, in those days actors were always switching into music theater [...] why that's either not even possible or supposed to make such a sensation nowadays, if it's possible at all, I don't know. The fact is, the works arose out of the performance practice of that time they're written for that.

The adapted version, as performed in 2004, was a compromise between what Wilgenbus hoped to do and what the Volksoper was willing to allow.

\section{Collections of stereotypes}

The Herzogin librettists defined America by referring to several clichés or stereotypes. That could have been done in a flat, simple way - but instead, they combined a wide range of elements to create a multifaceted image of the country across the Atlantic. The script presents a complex picture of American life that includes dedication to business and money; modernity as expressed in new cityscapes; the media of jazz music, jazz dance, and film; African-American culture, partly mixed and confused with African culture and thus viewed simultaneously as modern and primitive; ${ }^{8}$ and folkloric archetypes of cowboys and Indians.

As the show unfolds, it becomes clear that the European characters react differently to these disparate elements. The prince despises jazz and business, but he is captivated by cowboy-and-Indian mythology. His cousin, Princess Rosemarie, is intrigued by the modern aspects of American life, particularly jazz and skyscrapers. When Mary's private secretary, Bondy, proposes marriage to the prin-

8. For a remarkable exploration of Viennese responses to African-American culture, see James Deaville, "African-American Entertainers in Jahrhundertwende Vienna: Austrian Identity, Viennese Modernism and Black Success," Nineteenth-Century Music Review 3 (2006), 89-112. He discusses "what it meant for the cakewalk to be labelled a 'modern' dance and for the Viennese thus to be experiencing 'modernism' in their bodies when they danced it." (p. 91) 
cess, he invites her to live with him in his "little skyscraper, only 52 stories" - and the princess is enchanted by the thought that from the top story, they will be able to hear the angels' jazz band in Heaven!

Europe functions in the story as the polar opposite to America, and European culture is also represented by a collection of stereotypical elements, many of which were standard operetta fare even when no comparison to America was present. Traditional Europe is portrayed as a stratified society in which the noble class has many privileges - such as a stock of young women of lower standing who are available for dalliances - but also weighty obligations, such as the duty to marry for dynastic reasons. Court life is shown to be artificial and stifling, and the prince, in his nostalgic Wienerlied, reveals his belief that the lower classes in times past were happy. ${ }^{9}$

In Nußdorf steht ein kleines Haus -

Da schaut ein altes Paarl heraus

Und träumt, wie war's doch einst so fein,

Wie's einmal war, wird's nimmer sein!

Am Sonntag sagt der Franzel zu sein' Madel:

Geh, Schatzerl, komm, wir fahr'n zum "Roten Stadl”!

Im Sack nur einen Guldenschein,

Zehn Kreuzer kost' der Liter Wein.

(In Nussdorf stands a little house -

An old couple looks out

And dreams of how 'twas once so fine,

The way it was will never be again!

On Sunday, Franzel said to his girl:

Come, sweetheart, we're going to the "Red Barn"!

Only one coin in his sack,

A liter of wine cost ten cents.)

A charming scene representing the European way of life is the prince's encounter with his young cousins, the brothers of Princess Rosemarie (although the Regiebuch stipulates that they should be played by girls rather than boys). The children wear military gear and sing a marching song whose text emphasizes the externals of military life: uniforms, marching, drums, and so on. The satire is un-

9. All texts from the 1928 version are taken from the Regiebuch (that is, the libretto with full instructions on blocking and choreography): Julius Brammer and Alfred Grünwald, Die Herzogin von Chicago, Operette in zwei Abteilungen (zwei Akte mit einem Vor- und Nachspiel). Leipzig and Vienna: W. Karczag, 1928. I am extremely grateful to Michael Miller of the Operetta Foundation, Franz Neuwirth of the musical archive in Baden bei Wien, and Stefan Frey for their help in sending me this source. Translations are my own. 
mistakable, particularly in moments such as the following, when three lines sung by the children are followed by Sándor's declaration:

Der Tambour, der wirbelt den Stab in die Höh' -

Der Leutnant, der zwirbelt den Schnurrbart: äh! äh!

Der Hauptmann, der dicke, der schnauft hinterdrein:

Lieb Vaterland, lieb Vaterland, magst ruhig sein!

(The drummer, he whirls his stick way up high -

The lieutenant twirls his moustache: oh my!

The captain, the fat one, comes puffing back there:

Dear fatherland, dear fatherland, have no fear! $)^{10}$

The text alone raises questions about the fitness of the army to protect the land, and having the soldiers played by children intensifies the sarcasm. This idea is likely a reference to the opening scene of Tchaikovsky's opera The Queen of Spades, in which children play at being soldiers. The refrain adds to the comedy, as Sándor sings, answered by the children in four-part harmony, somewhat like a young barbershop quartet (Example 1):

EXAMPLE 1 "Wenn die Garde schneidig durch die Stadt marschiert," beginning of the refrain
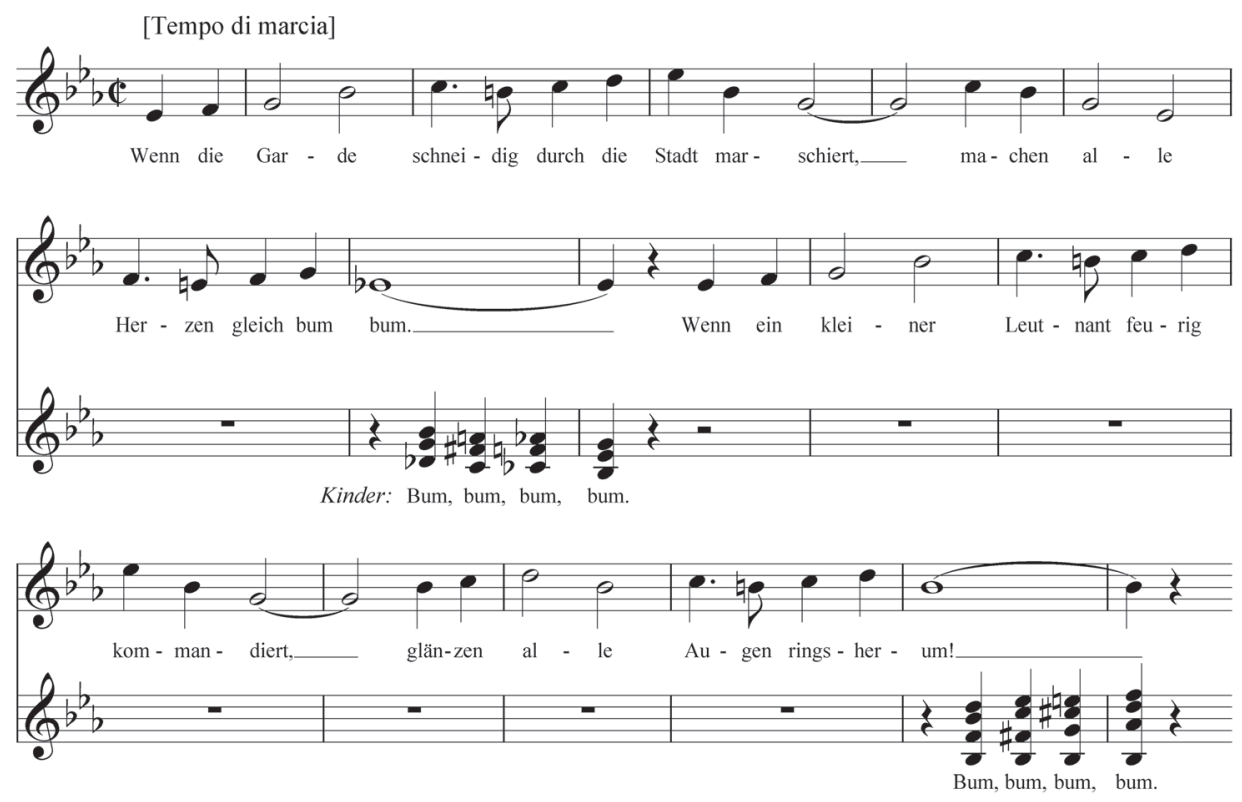

10. More literally, the final line reads "Dear fatherland, dear fatherland, you can rest easy," which intensifies the irony. I have succumbed to the temptation of creating a near-rhyme in place of a literal translation. 
(When the guard marches dashingly through the city,

all hearts instantly go "boom boom."

When a little lieutenant fierily commands,

eyes sparkle all around!)

In the 2004 version, this scene was extended through added dialogue, which worked well, as tenor Mehrzad Montazeri displayed a warm rapport with the children that made their dialogue engaging and charming. In 1928 all the children were supposed to be boys played by girls, but in the 2004 version the oldest is a cross-dressing princess named Soljanka - which sounds like a Slavic girl's name, but is actually a Russian soup featuring pickled cucumbers. Soljanka is a foil to the older royals, who accept the obligation to marry for dynastic reasons. She declares that she would not marry even if she were in love with the Prince of Pontevedro (the imaginary nation central to the plot of the Merry Widow); instead, she plans to go to America, drink cola, and build skyscrapers.

The Frey-Wilgenbus version continues to emphasize the artificiality of royal life by changing the text of the duet "O Rosemarie" between the prince and princess. As Frey explained, "it occurred to us that there were several musical numbers without direct action, and we wanted to try to bring things that are maybe in the dialogue into the music." Rather than a love song, it becomes a rueful confession that they are marrying for duty, as made clear by lines such as the following. ${ }^{11}$

O Ros'marie, o Ros'marie,

$\mathrm{Ob}$ ich dich liebe, Kind, das frag mich bitte nie!

Denn es gelten Staatsintressen

Mehr als jene von Prinzessen -

Du liebst nicht, dafür liebt dich die Monarchie...

(O Rosemary, o Rosemary,

Whether I love you, child, please never ask me!

For the interests of the state

Matter more than those of princesses -

You do not love; for that, the monarchy loves you.)

By framing the central conflict of Die Herzogin as one between continents, the librettists made an interesting choice: they presented each region as essentially harmonious, ignoring its internal struggles. Other operettas often emphasize intra-European

11. Quotations from the 2004 version are taken from the libretto; thanks again to Stefan Frey for this source. 
class conflict - may a landowner marry a Gypsy, or a countess fall in love with her estate manager? - but Prince Sándor identifies with all Europeans and even has a special bond with the Gypsy primás. Although America is represented as complex, combining rural and urban images and crossing racial boundaries, here too there is oversimplification. Mary's identification with jazz music and musicians is quite parallel to the prince's bond with Gypsy music in its crossing of class, ethnic, and economic divisions.

\section{First meeting: conflict in the Grille américaine}

While the dialogue of the Grille américaine scene was significantly changed for the 2004 version because of the scene's altered placement, what makes the scene effective is present in both versions: the exciting music and lyrics. The central conflict of the operetta, between European and American musical and cultural norms, is defined and established here, so this scene is absolutely crucial for the whole work.

It becomes clear early in the scene that the management of the bar has decided to follow the latest American trends, playing jazz music in order to attract the customers they now prefer. Tihanyi, the restaurant manager, says that "heirs to the throne don't count as guests nowadays" (Erbprinzen sind heute keine Gäste mehr) and goes on to list important guests, including a nouveau riche industrialist, "Mr. Goose, general director of the City-Center Salami Company" (Herr Generaldirektor Gans von der Innerstädtischen-Salami A.G.). The dialogue clearly reflects on the shift in economic power from the aristocracy to the business elite.

Prince Sándor, when he arrives, is horrified to hear the traditional musicians playing jazz, and particularly offended by the transformation of the first movement of Beethoven's Fifth Symphony into a "Beethoven-foxtrot by Sami Nussbaum." He challenges the musicians (led by his old friend the Gypsy prímás) to play some of his favorite tunes, and a musical confrontation ensues, as Mary and the prince compete for the band's allegiance. Eventually, this becomes a bidding war as each of them offers money - but Sándor, short of cash, is unable to top Mary's offer of five thousand dollars. Though she wins that battle, he wins the war, and his triumphant traditional music ends the scene.

Sándor's anti-American rant combines two elements: the idea that Americans rely on money to get what they want ("you will not sell your soul to the dollar-devil") and the racial-essentialist equating of jazz with primitive African music ("he dances like a Congo negro"). The first point is quite reasonable, given the situation that is unfolding at the bar, but the second has little to do with Mary's actions and simply reflects the prince's racial prejudices: he eventually declares "we'll throw the nigger out!" ("den Neger schmeißen wir hinaus!") Both critics and music scholars have observed that this moment in the operetta prefigured Nazi attitudes and actions against minorities. In my interview with Montazeri - himself a mem- 
ber of a minority in Austria, having immigrated there from Iran as a child - he admitted that he found it difficult to say these lines. He had to be persuaded by the director that it was important to the drama for the audience to witness the prince's transformation into a more tolerant person by the end of the show.

The scenario and text are well crafted, providing Kálmán with a solid framework, and within that he constructed strong musical contrasts, as I will demonstrate by presenting a few of his musical themes. As the finale begins, most of the orchestra plays the opening motive of the Beethoven symphony, in unison and at a fortissimo dynamic, answered by the brass playing crashing ninth chords that descend chromatically during the extended longer note (Example 2). The musical duel then begins: first Mary demands a Charleston, with her motive built on the descending third from Beethoven but adding the jazz element of syncopation. Sándor counters, supported by a florid violin solo from his friend the primás, by extolling traditional Viennese music. His Wienerlied eschews strong accents, using instead recognizable waltz meter, a melting legato melodic line, and sentimental chromatic inflections - particularly the melodic diminished fourths! That both are trying to persuade is indicated by their tempo markings: Allegretto grazioso for Mary, and Schwärmerisch, moderato ${ }^{12}$ for Sándor (Example 3).

EXAMPLE 2 Finale of Grille américaine scene, instrumental opening

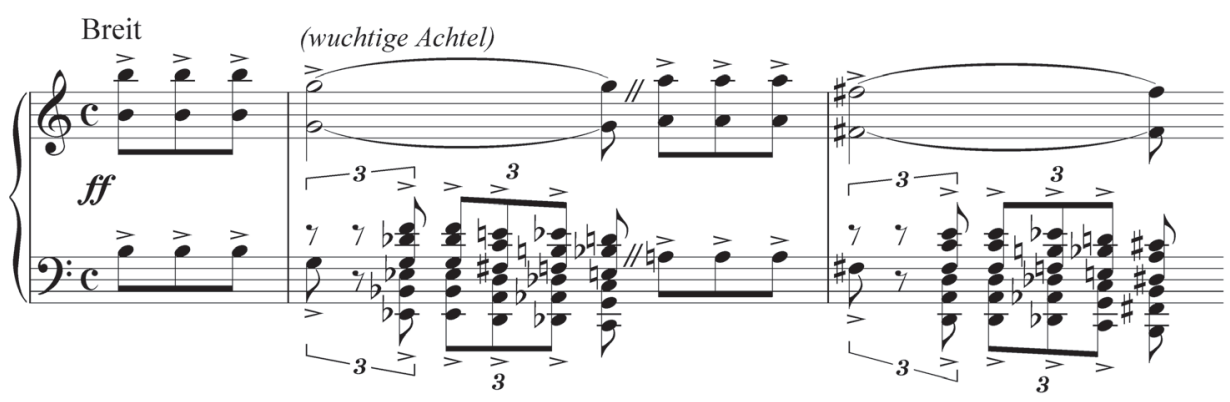

12. Possible translations for "schwärmerisch" include "wistful," "rapturous," "enthusiastic," and "gushing." http://en.bab.la/dictionary/german-english/schwaermerisch (accessed May 2016). 
ExAmple 3 Finale of Grille américaine scene, opening vocal lines

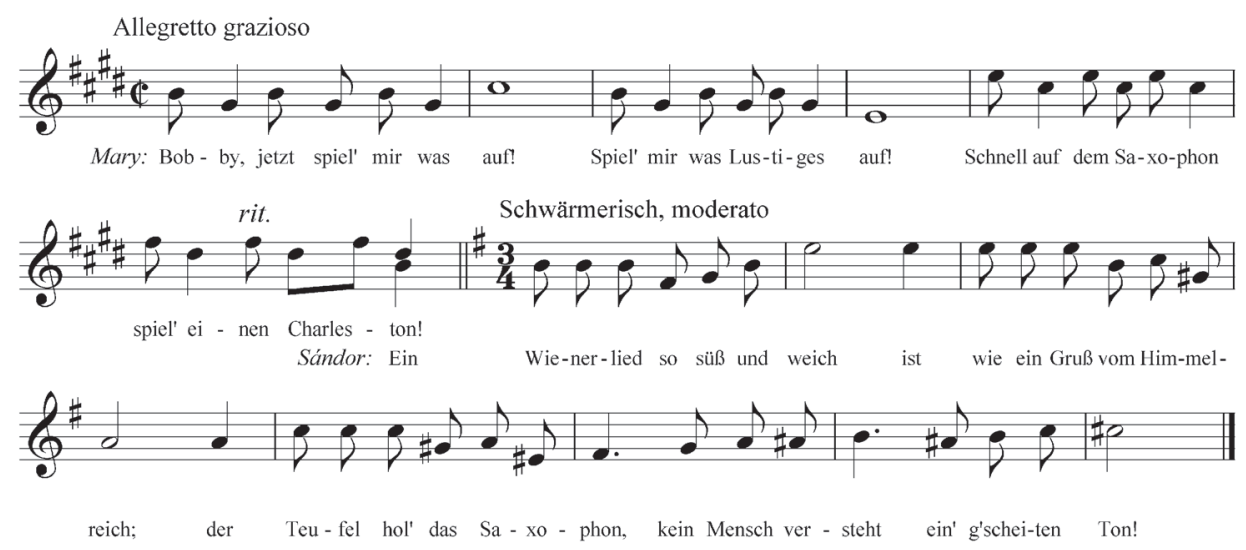

(Bobby, now play me something!

Play me something fun!

Fast, on the saxophone, play a Charleston!

A Vienna song so sweet and soft

is like a greeting from paradise;

the devil take the saxophone,

nobody understands one intelligent note!)

Mary achieves a temporary victory. This is indicated when the chorus joins her side with a unison paean to jazz (Example 4). The American and European musical styles are clearly distinguished through the contrast of meters (duple versus triple) and articulation (marcato versus legato).

ExAmple 4 Finale of Grille américaine scene, chorus.

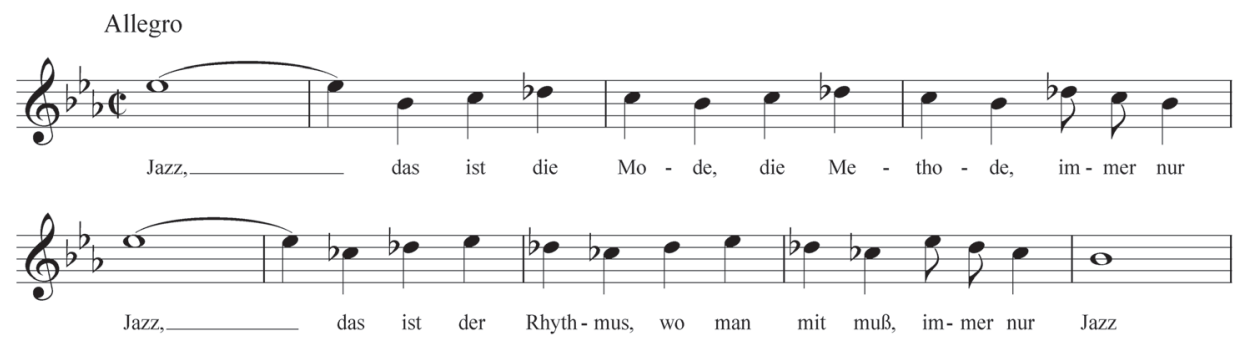

(Jazz, that is the fashion, the method, always just jazz, that is the rhythm one must go with, always just jazz) 
Sándor begins to win this contest, though, as he appeals directly to the Gypsy prímás - referring explicitly to his ethnic heritage:

$\mathrm{Pa} ß$ auf, alter Primas, bist du ein Mann!

Bist du ein Zigeuner, dann hör mich an, hör mich an!

So lang ein treues Herz das Lied der Heimat nicht vergißt,

So lange weiß ein armes Herz, wo stets sein Glück zu finden ist,

So lang durch deine Seele die Zigeunerweisen zieh'n,

Ein Gruß der Heimat, wo für dich die allerschönste Blumen blühn!

(Pay attention, old prímás, if you're a man!

If you're a Gypsy, then listen to me, listen to me!

So long as a true heart does not forget the song of home,

So long a poor heart knows where its happiness is always to be found,

So long as the Gypsy tunes move through your soul,

A greeting from home, where the most beautiful flowers blossom for you!)

The language here is striking. Sándor apparently identifies the Gypsy heritage with the European soul - an interesting contrast with the image of Gypsies as outsiders that had governed discourse about Gypsies from the seventeenth century onward..$^{13}$

Example 5 provides a sample of Sándor's melody here, whose evocative raised fourths from the Hungarian Gypsy scale create augmented seconds between the third and fourth scale degree.

EXAmple 5 Finale of Grille américaine scene, part of Sándor's solo

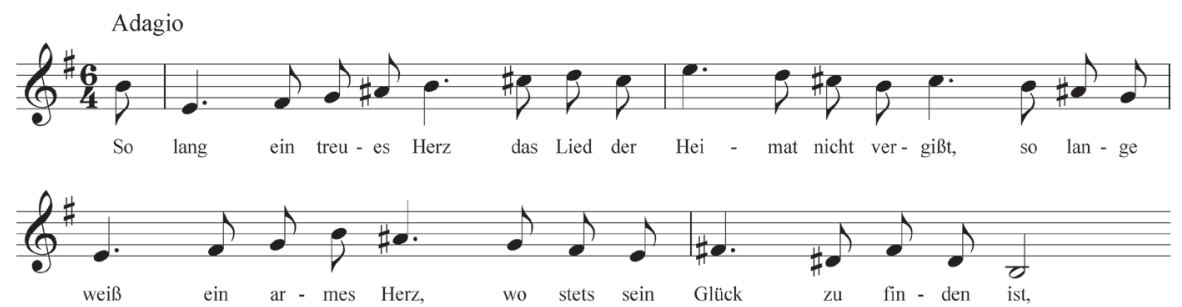

13. For an excellent overview of this topic, see Jonathan Bellman, "The Hungarian Gypsies and the Poetics of Exclusion," in The Exotic in Western Music, ed. idem (Boston: Northeastern University Press, 1998), 74-103. Bellman points out that "today, in a time of raised ethnic consciousness and political activism, it is peculiar that the Romani Gypsies still stand, in folklore and as a cultural stereotype, alone." (p. 74) He also points out that part of the stereotype is a belief that Romani Gypsies possess a natural musicianship not dependent on training, and that this links them with stereotypes held about African-Americans and their music (pp. 80-81). Montazeri pointed out a link between the two types of musicians in his comment on how the prince views the character of the Gypsy prímás: "he sees the primás as a friend, a counselor, who is everything for him [...] he thinks, why is he doing that with those others? He can't believe it that he would do something different behind his back - because he is a little more open as a person than the prince." 
This is not yet the end; the finale ends with a flourish as Sándor sings an extended csárdás. Its lassú, or slow section, is a rhapsodic lament for the passing of the Old World, with a few more anti-American zingers (quoted below), this then leads to the energetic friss.

Keine Rosen und kein Flieder,

Neuer Tanz, verrenkte Glieder,

Dollarrausch und Negerlieder,

"Jonny spielt auf!"

Yankee hat die Welt verpachtet!

Wer sich einstens das gedacht hätt einst einmal!

Primas, laß dich nicht verdrängen

Von Amerikas Gesängen!

Spiel dein Liedel auf der Fiedel

Wie einst einmal!

(No roses and no lilacs,

New dance, distorted limbs,

Dollar addiction and nigger songs,

"Jonny spielt auf!"

Yankee has leased the world!

Who would have thought it, way back when?

Prímás, don't let yourself be driven out

By America's songs!

Play your tune on your fiddle,

Like long ago!)

Sándor wins the scene - but in the process, Kálmán makes evident the ties between jazz and csárdás, as both these dance styles feature syncopation and chromaticism. Sándor's anti-American attitude will eventually wane as he comes to love the Charleston along with his European dances.

\section{Ausländerfeindlichkeit in Austria}

For some audience members in 2004, the name "Chicago" in the operetta's title likely recalled a political slogan from the previous decade. In the Vienna elections of 1991 and 1996, the right-wing Freedom Party of Austria (FPÖ) used the slogan "Wien darf nicht Chicago werden" (Vienna must not become Chicago), referring to the 1920s image of Chicago as a haven for gangsters and organized crime. Chicago was a very different city in the 1990s than in the 1920s; when the slogan was 
reused in 1996, the Mayor of Chicago, Richard M. Daley, lodged a formal protest. ${ }^{14}$ Making the shift to anxiety about the Islamic world, in 2005 the FPÖ reused the slogan with one word replaced: "Wien darf nicht Istanbul werden," building on and inciting fear of Turkish immigrants. As in other parts of Europe, there has been much concern and publicity in Austria about Muslims (mostly Turks) who have settled there, ranging from debates about headscarves to concern about polygamy to anger over new mosques in traditionally Catholic communities. During my interviews about the Herzogin production, the 2009 elections for the European Parliament were about to take place, and the same party plastered the city with posters reading "Abendland in Christenhand" (The West in Christian Hands). This hostile slogan was criticized by secular and religious leaders both in Austria and abroad. ${ }^{15}$

In 2017, this debate lives on in new forms as a result of the Syrian refugee crisis and the mixed responses it has received in Europe, North America, and the Middle East. Compassion for refugees fleeing war is complicated by fears that the influx of foreigners will lower the European standard of living and that these immigrants may commit violent terrorist acts against the West. The attacks in Paris and San Bernardino have intensified the political and cultural controversy. As I wrote this in the week of the Orlando nightclub massacre, the range of responses in the US was immediate and real, particularly as a presidential election was approaching.

The FPÖ election slogan implied that Chicago was a dangerous, crime-ridden city spinning out of control, while the operetta conjured images of a modern, technological city sparkling with jazz and fizzy cocktails. While not necessarily contradictory, these are very different ideas of life in America. In 2009 Rudolf Berger told me that he did not believe that audiences would have made the association with the FPÖ slogan from a decade earlier, but I suspect that some of them remembered - and appreciated the irony. ${ }^{16}$

\section{Euro-American politics and the Iraq war}

When I began this project, it had occurred to me that the Volksoper might have chosen this operetta as a commentary on current politics in 2004, particularly the

14. Ironically, as all Chicago residents know, one of the prominent sausage companies in Chicago is the Vienna Beef Company. "Vienna ${ }^{\circledR}$ Beef was founded in 1893. Austrian-Hungarian immigrants Emil Reichel and Sam Ladany introduced their family frankfurter recipe at the legendary Columbian Exposition." (http:// www.viennabeef.com/our-company, accessed May 2016) This is particularly relevant since Mary Lloyd's father is supposed to have begun his business career as a sausage-maker before diversifying into oil.

15. Images of posters with these slogans can easily be found online. See, for example, http://www. demokratiezentrum.org (accessed February 2016). There are also numerous articles on these slogans and the political debates they provoked.

16. Wilhelm Sinkovicz's review in Die Presse on 12 December 2004 had the headline "Wien kann nie Chicago werden" (Vienna can never become Chicago). 
Iraq War that began in 2003. I soon found that Austrian critics had made the same point. Derek Weber had commented in the Salzburger Nachrichten on 13 December 2004 "That people - not only at the Volksoper - are beginning to rediscover this operetta, is owed of course to the debate over the cultural differences between the USA and Europe which has begun as a consequence of the Iraq war." ${ }^{\prime 17}$ Christoph Irrgeher, for the Wiener Zeitung, wrote more ironically and indirectly: "Must this Herzogin look quite so old - although laments about an America that carries out its dominating little dance on distant thrones are not as old as Methuselah?"18 And the News review succinctly commented "not to mention the current relationship between Europe and the United States."19

Despite this apparent connection between the Herzogin's plot and current events, Rudolf Berger, Dominik Wilgenbus, and Stefan Frey all told me that the immediate political situation had not been a factor in the choice of this work. I learned of some external reasons, not linked to European-American politics, which help to account for the fact that several productions of Die Herzogin von Chicago took place around this time. Kálmán had died in 1953, so 2003 was a logical moment for many companies to consider putting one of his works in their repertory. In connection with this anniversary year, his daughter Yvonne strongly advocated for this work and encouraged companies to consider reviving it. Some informants also commented that theater companies often choose a work that has been successful elsewhere. Finally, there was the particular circumstance of the Entartete Musik series planned for the 2004-2005 season. All these points led me to set aside my initial theory that the Vienna production was intended as direct political commentary on the current situation - but it did not eliminate the thought that the audience might have received it in that spirit, independent of the production team's intentions.

One question that came up in several interviews was whether audience members experienced the performance primarily with relation to the work's own time period or to the time when it was performed. My informants took different perspectives on the relative importance of the two decades. Berger, for example, took the somewhat Freudian view that because events of the 1920s and 1930s have been ignored in Austrian public discourse, theatergoers from older generations were drawn to this work precisely because it confronted those repressed issues. Norine

17. "Dass man die Operette nun - nicht nur an der Volksoper - wiederzuentdecken beginnt, verdankt sich wohl der Debatte über die kulturellen Unterschiede zwischen den USA und Europe, die im Gefolge des Irakkrieges in Gang gekommen ist."

18. "Muss diese 'Herzogin' denn gar so alt aussehen - obwohl die Klagen über ein Amerika, das sein dominantes Tänzchen auf fernen Thronen vollführt, nicht eben nur aus Olims Zeiten stammen?" The expression "Aus Olims Zeiten" does not refer to a person called Olim, but rather means "very long ago." "Schlummertrunk mit Miss Mary," Wiener Zeitung (14 December 2004), 14.

19. "Nicht zu reden vom heutigen Verhältnis Europas zu den Vereinigten Staaten.” Anonymous, "Angesehen: Kritiken der Woche: Fulminanter Korngold, erfreulicher Nestroy, zweifelhafter Kálmán in Wien," News 51/04, 136. 
Burgess, who played the title role, was inclined to think that Austrians have been dragged through those issues so many times that, even though the problems are unresolved, they would prefer to relate the Herzogin to the present rather than the past. Wilgenbus argued that material from the 1920 s was especially appealing to the audiences because they were facing a similar world situation of economic crisis, unemployment, and so on. Montazeri also mentioned this parallel, and along with it the tendency of societies to swing rightward politically and become more intolerant of difference at times of economic peril. Burgess made the connection between present and past as follows:

\begin{abstract}
Well, I think that the reason for putting it on was 1928, and here we've unearthed something that hasn't been done, and let's make a historical moment. I think it was just sort of - whatever word you want to choose, fortuitous or serendipitous, that sounds too positive - it just so happened that it kind of made people see, I hesitate to even say parallels, but it just seemed to happen that way. [LF: So there was something that clicked with the present circumstances as well as the past?] Yeah, and it was imposed from without [...] I don't believe Dominik had that in his mind really at all when he was writing it [...] it was just that externally, people found a resonance that jumped from the 1928 situation [...].
\end{abstract}

It seemed clear from these comments that some of the older spectators likely viewed the production through the lens of their own memories from the time surrounding World War II. Others, particularly the younger members of the audience, may have viewed it with contemporary issues in mind.

To explore this, I asked questions about Austrian attitudes towards America in 2004, and about how likely Austrians are to associate theatrical works with current events. I discussed these issues particularly with my group of Austrian scholars, so most of the following comments come from them. For professional reasons, some of them preferred not to have their quotations identified, so I present their views anonymously. While some interviews were in German, I present all these comments in English.

I did not ask my informants to characterize the full spectrum of public opinion, but rather to focus on the circles they knew best: university people, intellectuals, artists, and so forth. There was an overwhelming consensus that these circles - and perhaps Austrians altogether - were unified in their dislike of the Bush administration. It was also made clear that Austrians separated their view of America the nation from the Bush government. Here are six sample quotes:

It was seen very simply: the business interests that the USA has in Iraq, which have to do with oil, and people thought, simply, that the situation in Iraq has gotten worse through the American invasion. [...] The war made a very negative im- 
age of the USA, yes. And if they had wanted to take out Saddam Hussein, there would have been other possibilities, because I mean, [the CIA] isn't stupid, is it?

After it became clear that all the arguments for the Iraq war had been constructed, were pure fiction, at that time nobody considering him- or herself an intellectual here would have any positive statements about the US government. [...] Europeans thought, towards the end people were thinking, Bush really is catastrophic.

Where it starts to become incomprehensible for Europeans, I think, is when claims are made about having to do something in the name of national defense, security, protecting your borders. You're bombing a country halfway around the world that hasn't declared war on you, that doesn't have any interest or capacity to invade your country [...] that still is a little bit of a tough concept for Europeans. What flabbergasted me, perhaps, was the lack - the total lack, as far as I could tell anyway, of a viable opposition in the United States. It was all against us, or you're for us or against us, and that was it - someone drew a line in the sand and everybody jumped.

The year 2004 was important, of course, because of the election. It was the general opinion here in Austria that the election would mean the end of Bush's term as president. Once he was reelected, there was a great deal of surprise, shock, disappointment at the continuation of that, and the sense that we were in for four more years of a great deal of political difficulty.

The whole time, really, up to Obama's election, opinion was negative. It wasn't just about the war, for many intellectuals it had to do above all with not signing the Kyoto Protocol. The environmentalists saw that especially as a crime, and that was the general opinion.

Thank God, in Europe nowadays, also in America with Obama everything is open, yes? All have hope, everyone, really, everyone laughs when America is spoken of, everyone smiles, yes? Everyone is happy, it is not like before.

These comments reveal that many Austrians viewed the Bush administration with dislike and cynicism, because of the Iraq War and other policy decisions, and felt very hopeful when it came to an end with the election of Barack Obama in 2008. It is significant that the premiere of Die Herzogin on 12 December came just a few weeks after the 2004 election, when it became clear that George W. Bush would serve as president for another four years.

Furthermore, as Norine Burgess remarked, Europeans and North Americans frequently have different levels of political awareness. 
I think Austrians inhabit a much more politically informed world than - well, than I do, anyway - I think that a lot of us in North America, where we're not influenced [...] by very much - but Austria, being part of the European Union [...] everybody's position affects everybody else.

Consider the Grille américaine scene again with the 2004 world situation in mind. How might the arrogant approach of Miss Mary Lloyd have been interpreted by Austrians at a time when an American president was rejecting international agreements and taking a stand-alone approach to worldwide problems like global warming, while at the same time leading the West into a war most Austrians did not approve of, under the banner "Coalition of the Willing"? As one of my Vienna informants pointed out,

they're used to Regietheater here, where old pieces are put into modern contexts [...] that are highly applicable to what's happening. In fact they're almost looking for it [...] and it happens all the time, it happens in opera, it happens in plays, it happens in operetta - why not? - so I think seeing this as a potential platform for that kind of thematization is perfectly plausible.

And, on the plot of the Herzogin:

I think it resonates the idea of unilateralism, of walking into a situation and not knowing the subtleties of local culture, local perspectives and long-term and short-term consequences of those ambitions. The parallels are pretty compelling.

Die Herzogin von Chicago is a work of theater, its plot designed to be dramatic and exciting. It is based on stereotypes and clichés - not surprisingly, as operetta has never been known for realism. Yet the immediate political circumstances surrounding the revival in 2004 had much in common with the fictional situation being presented on the stage.

\section{Critical responses to the 2004 Herzogin and "How One Plays Operetta"}

Critical response to the 2004 production was mixed, and more negative than positive. ${ }^{20}$ The criticism came at the situation from various angles. Some complained

20. The Volksoper helpfully provided me with their complete set of reviews of the production, from newspapers in Austria, Germany, Switzerland, the UK, and the US. Many thanks to Frau Mag. Eva Koschuh of the Volksoper publicity office. 
that the original work was weaker than Kálmán's earlier hit shows and not worth reviving, while others disapproved more of the choices Wilgenbus and Frey had made in adapting it. Some disliked the staging and lambasted the choreography. Some complained about the orchestra under the leadership of Karen Kamensek (who was replaced soon after the premiere), while others praised her conducting and sense of both musical styles. There was much dissatisfaction with the singing and acting of the two lead performers (although some liked Montazeri's Prince Sándor), along with praise for some of the performers in secondary roles.

The critics were well informed about the place of Die Herzogin in Kálmán's oeuvre and about its historical significance as a late-1920s piece that would soon be declared entartete Musik. Some were familiar with recent performance history, such as the Decca recording and the Dresden production earlier in 2004. ${ }^{21}$ On the whole, the criticism seems grounded in musical and historical knowledge - yet at the same time, several comments betray a model of appropriate operetta performance that is more nostalgic than historically accurate. Some sample comments reveal this:

Much lamented and never contradicted is the sad fact that there simply is no longer any real diva capable of making a thrilling entrance in an evening gown. ${ }^{22}$

[...] but true operetta charm bubbles from guest star Peter Matic as the king, Josef Luftensteiner as the finance minister and Sándor Németh as the minister of state. ${ }^{23}$

The art of sensing the innate rhythmic possibilities of this music and realizing them tastefully while maintaining precision cannot be learned by pushing a button; one must simply be born into it. All the participants in this beacon of charmlessness should be urged to make an excursion to the Beograd Restaurant behind the Naschmarkt, where one can learn by listening to two Hungarian musicians how one plays operetta." ${ }^{24}$

21. Sieglinde Pfabigan comments on the Dresden performance of an unaltered version that filled the house in the Neue Merker review; her awareness of other productions is not surprising, as this periodical is specifically devoted to opera.

22. "Viel beklagt und nie widerlegt worden ist zum Beispiel das traurige Faktum, dass es eine rechte Diva, die imstande wäre, einen rauschenden Auftritt in der Abendrobe zu absolvieren, einfach nicht mehr gibt." Wilhelm Sinkovicz, "Wien kann nie Chicago werden," Die Presse (13 December 2004).

23. "aber wahren Operettencharme versprühen Gaststar Peter Matic als König, Josef Luftensteiner als Finanzminister und Sándor Németh als Staatsminister." Irmgard Steiner, "Publikumserfolg mit Tanz und Pomp," Neues Volksblatt (13 December 2004), 15.

24. "Die Kunst, die dieser Musik innewohnenden rhythmischen Möglichkeiten aufzuspüren und bei Beibehaltung der Präzision mit Biss zu realisieren, kann man nicht auf Knopfdruck lernen, man muss dazu einfach geboren sein. Allen an diesem Fanal der Charmelosigkeit Beteiligten wäre eine Exkursion in das hinter dem Naschmarkt liegende Restaurant Beograd nahe zu legen, wo man zwei ungarischen Musikern ablauschen kann, wie man Operette spielt." Peter Vujica, "Armer Kálmán - operettungslos verloren," Der Standard (13 December 2004), 21. 
Bubbly charm, elegance of carriage and costume, witty repartee and effortless dancing are implicitly identified by these critics as the measure of operetta style and success. Without those, we may conclude, a performance is not successful operetta, no matter how relevant or meaningful its social and political critique may be. Ironically, Christoph Irrgeher, in his review for the Wiener Zeitung, took the opposite perspective: he saw the production as aimed too much at facile box-office success and commented that this leads to the "paradox of a conservative Regietheater" 25 - on which more below.

First, though, a digression regarding the final comment above, by Standard reviewer Peter Vujica. I was amused to find an online response to this review which read:

\begin{abstract}
Music critic Vujica disqualifies himself with the statement about the Beograd, because anyone with the slightest musical education cannot hold out long listening to the live music there. The fiddler may perhaps have Lehár's and Kálmán's music in his blood, but his intonation is so unbelievable that it hurts. But this doesn't seem to disturb Herr Vujica, which brings up a comparison between him and the critic in Georg Kreisler's "Musikkritikerlied" ["weil ich unmusikaaaalisch biiin!”]
\end{abstract}

I myself once had a meal at the Café Beograd, and I am quite sure that I heard the same violinist the Internet commentator mentions. The musicians invited me to sing Schubert's Ständchen with them, and their strong tendency to use rubato made the experience rather unusual.

Despite the commentator's aspersions, Vujica was actually trained as a music theorist and composer; his works were published under the name Peter Daniel Wolfkind, "little wolf" being a translation of his Serbian surname. ${ }^{26} \mathrm{He}$ was evidently willing to overlook issues of tuning in favor of the perfect timing he appreciated in the café musicians. Unspoken but strongly implied in his comment - which comes directly between his discussion of American conductor Kamensek and Canadian singer Burgess - is that operetta musicians must be born into the ethnic and cultural world of the music; it cannot be learned. ${ }^{27}$

25. "Paradoxon eines konservativen Regietheaters" in "Schlummertrunk mit Miss Mary," Wiener Zeitung (14 December 2004).

26. See Thomas Trenkler, "Peter Vujica gestorben," Der Standard (26 December 2013), for more on Vujica's many interests and accomplishments.

27. Perhaps Vujica was also implicitly questioning the role of Wilgenbus and Frey, since they are German, not Austrian. I have encountered this same attitude about whether anyone from outside Vienna can truly perform and understand Schubert's music. Statements like this go beyond making claims of truth by asserting that the speaker is a higher authority. Perhaps it is no coincidence that the seminal thinker who analyzed this type of rhetorical move was Ludwig Wittgenstein - in his later philosophy, particularly the Philosophical Investigations - who was himself from Vienna. 
I asked all my informants who were involved with the production how they interpreted this type of criticism, and what they thought was meant by correct operetta style. The replies moved in two directions. One point made was that this attitude may have reflected Viennese theatrical politics more than the production itself. Rudolf Berger was in his last year as the director of the Volksoper, and the negative criticisms were viewed either as an indignant reaction to his decision to resign, or possibly as a campaign to force him to resign. Berger himself replied to the question by saying

First of all, I don't know what correct operetta style is, and I am certain that if you were to ask one of these critics what it is, he could give you no answer. Those are the clichés and the superficial answers that often come, particularly regarding an unfamiliar work.

This point of view discounted the accusation as one with little substance that might be disguising other motivations.

The two singers seemed to acknowledge that there is a true operetta style. (Burgess said "Well, if there is, they [meaning the Volksoper] own it.") However, they also noted that Die Herzogin challenges that very notion, since it is about a direct clash of musical traditions. Thus, Burgess again: "It probably isn't true operetta style, because I suspect he wasn't really writing it as true operetta, because he was consciously making this hybrid. I mean, that's what the story is about." She also commented that the critics tend to defend what they perceive as authentic, but "it could be a certain amount of the dog defending the house without really knowing if the gold's in the house or not." Montazeri summed up the genre issue by saying "for me, the piece is not just operetta. For me it is play, it is theater, it is cabaret, cartoons, there is something for everyone in it. There is opera, operetta, musical, and cabaret in it."

\section{Audience responses}

For the management of the Volksoper and for some critics, the conservatism of the Viennese operetta audience is self-evident. Birgit Meyer, who was the dramaturge for the Volksoper for six years and was central to planning the Entartete Musik project, spoke in a 2005 Salzburg symposium about the conflict between artistic freedom and the need to attract an audience. Speaking of a controversial VolksOper production of Kálmán's Gräfin Mariza in 2002-2003, she wrote that

here [in the operetta genre] the question arises most quickly whether a new, contemporary interpretation is allowed. The predominantly elderly audience links operetta to numerous nostalgic memories [...] new interpretations are of 
no interest; the audience that is open to new perspectives and reinterpretations does not attend operettas. ${ }^{28}$

Perhaps sarcastically, the reviewer for the News made a similar point about the Vienna audience as a way of skewering Wilgenbus's directorial choices:

It's true: the operetta public arouses fear. Its rage, if something is not the same as it always was, can be comprehended no more than the Fatwa against Salman Rushdie. However, one must not be so afraid that one no longer exercises direction. And so we experience Kálmán's operetta Die Herzogin von Chicago in a Regie-free space. ${ }^{29}$

This critique is absurd, considering that Wilgenbus and Frey made substantial changes in the work through their adaptation alone - but I cite it here as evidence of this widespread idea about the Viennese public.

According to Wilgenbus, the theater management rejected his plan to use jazz musicians in part because they feared that the public would not accept that type of stylistic intervention. Given all these concerns and preconceptions, it is noteworthy that the 2004 production aroused much more enthusiasm among audiences than among critics. Even though the reviews date from early in the run of the show, some of them make note of this discrepancy. For example, the reviewer for Die Furche, writing just a few days after the premiere, commented that the production was "enthusiastically celebrated by the public, mercilessly ripped by the critics." 30 Similarly, Rudolf Berger remarked to me that

Vienna is sadly, so far as people go here - and this applies to the press just as to the public - not a very curious city. And I was positively surprised how good the resonance was with the audience, and I'm also surprised - this concerns not only Vienna, thank God - about the sales numbers of the DVD, which were substantially higher than we expected. [He mentioned that it was nominated for a Grammy award.] So, it fared very well, and in Vienna with the audience as well, people liked it. The criticism, which was very mixed, I remember that

28. Birgit Meyer, "Regietheater im Spannungsfeld zwischen künstlerischem Anspruch, Kulturauftrag, ökonomischen Zwängen und Kulturpolitik am Beispiel der Volksoper Wien: Ein Statement aus dem Theateralltag," "Regietheater": Konzeption und Praxis am Beispiel der Bühnenwerke Mozarts. Mit einem Anhang zu Franz Schrekers “Die Gezeichneten”. Vorträge des Salzburger Symposions 2005, hrsg. von Ulrich Müller und Oswald Panagl (Anif/Salzburg: Müller-Speiser, 2007), 104. My translation.

29. "Es stimmt schon: Das Operettenpublikum ist Furcht erregend. Seine Wut, wenn etwas nicht so ist, wie es immer war, kann von Nichtfundamentalisten so wenig nachvollzogen werden wie die Fatwah gegen Salman Rushdie. So vor ihm fürchten, dass man überhaupt nicht mehr Regie führt, muss man sich allerdings auch wieder nicht. Und so erleben wir Kálmáns Operette 'Die Herzogin von Chicago' im regiefreien Raum." “Angesehen: Kritiken der Woche," News 51/04 (date unknown), 136.

30. "vom Publikum begeistert bejubelt, von den Kritikern gnadenlos verrissen." Die Furche (16 December 2004). 
too, it doesn't surprise me in the slightest, because you disorient people with something like that, and that is always difficult in Vienna.

This comment from the director of the theater reflects his caution about doing something new and challenging - but also confirms that the audience response was very positive and much more so than that of the critics.

There is a paradox here. Critics objected to the show partly because they judged it to be too daring for Vienna audiences (with Irrgeher as a notable exception). However, the audiences did not comply with the critics' instructions and expectations about what they were supposed to like. Wilgenbus shared the following anecdote:

[A critic] first ripped the performance, my direction, and then a day later there was another article by that critic in that paper, then he tore apart the Viennese public because they liked it, and he asked "how can that be, that our Vienna audience liked this kind of thing?" Then, thank God, he got letters from readers, they told him that he should state his opinion and they would take care of their own. ${ }^{31}$

Birgit Meyer mentioned in her Salzburg lecture that young audiences who attend open rehearsals of operettas are much more open to new ideas and interpretations than the traditional Volksoper public. When I was in Vienna in 2009 to conduct these interviews, I attended a Volksoper performance of Lehár's operetta Das Land des Lächelns, which is set partly in Austria and partly in China. This was my opportunity to watch Montazeri perform, as he played the leading tenor role of Sou Chong. The production was notable in two ways. This operetta is clearly an exoticist work that reflects many outdated attitudes of early twentieth-century Europe, but given that basic situation, the "Chinese" section of the work was made more authentic by the presence of actual Chinese ribbon dancers on stage. Second, a much younger audience was present and seemed to be enjoying the show very much. ${ }^{32}$ These observations, while anecdotal, suggest that the Volksoper may be moving in new directions that bring in a younger audience, thus overcoming the hurdle of the reactionary public that wants everything to remain the same.

31. "Er hat erst die Aufführung verrissen, meine Regie, da hat er das Wiener Publikum verrissen, dem das gefallen hatte - er fragt, wie kann das sein, das unserem Wiener Publikum so was gefallen hat? Da hat er gottseidank Leserbriefe bekommen, man hat ihm schon gesagt, er soll mal schön seine Meinung sagen, ihre Meinung würden sie dann schon selber sagen." I have not been able to find this whole sequence of events in the reviews I was given, which included only one from each periodical.

32. In fact, this was true of two performances that week. My partner attended another performance, as we were sharing care of our young daughter, and he saw the same type of audience on that evening as well. 


\section{The expanded role of film in the 2004 production}

The librettists of Die Herzogin included references to popular film as one of the signifiers of American culture. Most important to the plot is the sudden appearance, toward the end of the operetta, of a mysterious stranger. He appears to be courting Mary - which makes Sándor jealous - but when he finally reveals his identity, it turns out that he is Charlie Fox, the director of Paramount Fox Films in New York. He is in Europe to pursue the studio's latest idea of basing movies on real life, and he wants to arrange for the story of Mary and Sándor to be filmed - but, as he explains, "we need the happy end" - and therefore he has come to persuade the couple to reconcile. Thus, he acts as a catalyst, bringing the two together for the resolution of their quarrel and the required happy ending.

The importance of film in America has been introduced before this in the scene leading up to the duet "Rose der Prairie." Mary asks Sándor whether he truly believes there is no romance in America, and part of his answer is a reference to a recent Fox film he has just seen: "The Interrupted Rummy Game in the Kentucky Primeval Forest." While this comical title may not sound particularly romantic to us, Sándor specifically says that it was: "War sehr romantisch!" which suggests his idealization of the wilderness as a positive symbol of America. In 2004, this line was omitted - probably because the greatly expanded role of film made it unnecessary.

As mentioned above, Wilgenbus and Frey had reorganized the scenes so that the new structure began to resemble cross-cutting technique in a film. Instead of bringing in a film director only at the very end, Wilgenbus explained that

the aesthetic theme of film was very important in the ' $20 \mathrm{~s}$ - just then, there were so many artists who came from theater or even from totally different realms who grappled with the medium of film, such as Bert Brecht [...] And we thought it over, what a shame, such potential, for today's public very very attractive - and we considered, we can build that in as a red thread through the story.

They did this by transforming Bondy, making him not only Mary's secretary but also a budding film director who comes along on the trip to make a movie of the whole story. He frequently carries a film reel, and sometimes steps out of the dialogue to order a specific cut or camera angle.

Romantic irony - the awareness that this is a story being told through art - is created in both versions by this idea of filming the story. This irony raises doubts about the reality of the "happy end." It also opens the door to a particularly delightful scene in the adapted version. "Rose der Prairie" is a role-playing game: Mary entices Sándor into his idealized America by enacting with him a love scene in which she plays the role of an Indian maiden and he that of a cowboy. Wil- 
genbus and Frey staged this with an inserted animated film, thus referring to the animated cartoon genre that dates from the same period as the operetta. Walt Disney's first cartoon with synchronized sound, Steamboat Willie, was also made in 1928.

The animation begins in the middle of a dialogue. As the couple are discussing their shared frustration at the burden of wealth and wishing that they could be more normal, each in turn is replaced by an animated figure. We still hear their voices as we watch their animated surrogates move among the large letters of the word "Glück" (happiness). The prince is mocking the business-focused American spirit, and Mary counters that belief by exclaiming: "do you think there is no romance in America? Haven't you heard of the poetry of the prairie?" She is suddenly transformed into an archetypal Indian woman, and then Sándor notices that he is in full cowboy garb and that the smooth letter he was sitting on has become a prickly cactus. The invisible singers then perform the duet, while their cartoon surrogates go through an adventurous canoe ride during which they cascade over a waterfall and narrowly avoid arrows shot by other Indians. When the characters return to their bodies, they do so separately: at first, Sándor remains a cartoon while Mary reappears as a flesh-and-blood woman. Eventually, both characters are back onstage, wearing rather ridiculous cowboy and Indian costumes until the end of the scene.

The Trickfilm was appreciated by the critics and hailed as one of the highlights of the evening. There was not a single negative comment on it in the reviews except that some argued that as Wilgenbus was not the animator, he should not get the credit for this clever moment. This brief dip into another art form fulfills several purposes. First, it brings out the connection of this operetta to film, which Wilgenbus and Frey wanted to make more explicit. Second, it expands the link to American culture - while film is of course a European genre as well, the early stages of cartoons are particularly associated with American popular culture. Third, it emphasizes the importance of archetypes and stereotypes in the work as a whole, demonstrating that Europe and America cope with their direct encounter by conjuring up imagined versions of one another. Finally, through the non-simultaneous transformations of the characters, it intensifies the romantic irony and the sense that there are various layers of reality.

Musically, Kálmán chose a hybrid style for the duet, combining European and American elements. The opening theme evokes "primitive" music through its even duple-meter rhythms and pentatonic melody. He refers both to jazz and to Native Americans through the inclusion of banjo, saxophone and Indian drums. Mary's opening phrase is shown in Example 6. Immediately after that, Sándor replies with a repetition of her melody a fifth higher (a common device in Hungarian folksong) that then moves in a new direction, ending with an evocative phrase in the Hungarian Gypsy scale that features a lowered sixth and raised seventh; see Example 7a. 
The duet's refrain returns to pentatonicism, but with underlying harmonies in E major rather than E minor, as shown in Example $7 b$. By classifying the major mode as a traditional European element, we could perhaps read the ethnic path of the whole duet as American-Hungarian-blended.

Example 6 "Rose der Prairie," opening theme

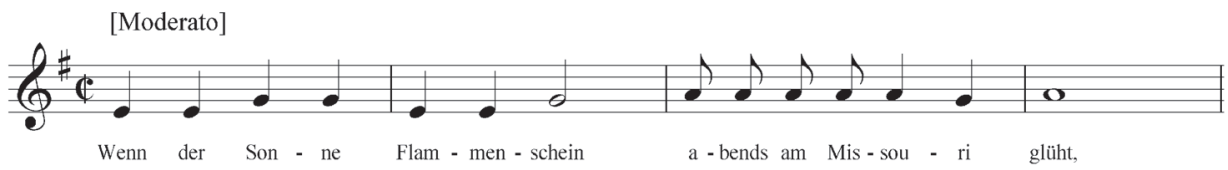

(When the sun's flaming light glows on the Missouri in the evening

.)

Example 7A "Rose der Prairie," end of verse and beginning of refrain

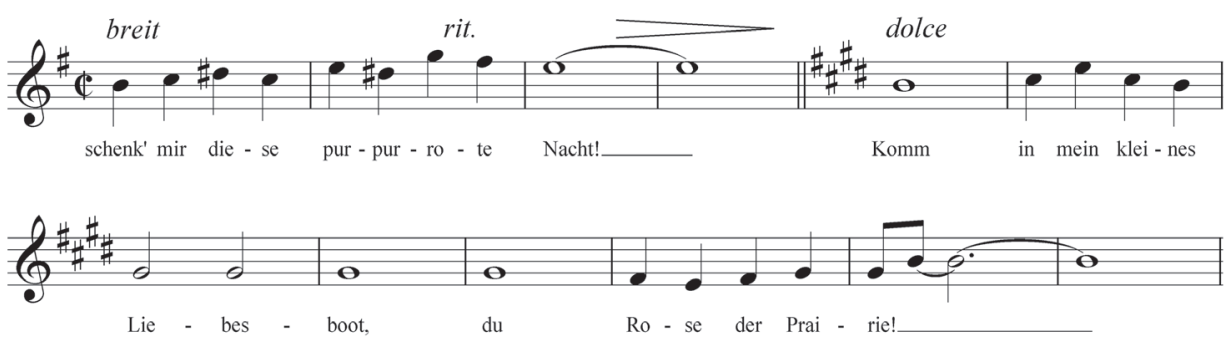

(Give me this purple-red night.

Come into my little love boat, you rose of the prairie!)

ExAmple 7B "Rose der Prairie," last line of refrain

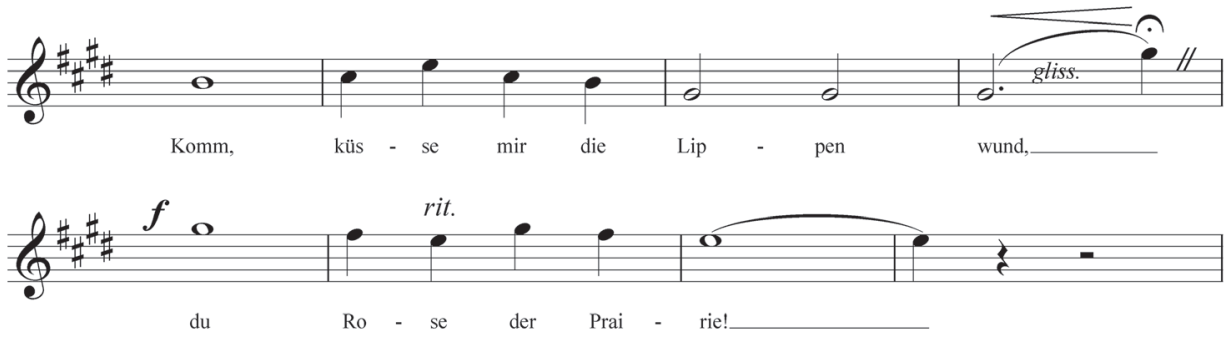

(Come, bruise my lips with kisses, you rose of the prairie!) 
The theme of Example $7 b$ is notably similar to Stephen Foster's song Old Folks at Home, a classic emblem of American folk style: the refrain opens with the same rhythm as Foster's song, and the opening melody of Old Folks at Home (Example 8) is heard at the end of the final phrase. Like "Rose der Prairie," the Foster song also begins by referring to the banks of a river. The theme also strongly resembles the opening of Dvořák's string quintet opus 97 (Example 9), which he wrote during his sojourn in the United States in the 1890s ${ }^{33}$ Kálmán may have been quoting these particular pieces; if not, he was modeling his melody on the same musical features that Dvořák and Foster identified as the American sound.

Example 8 Foster, Old Folks at Home, opening melody

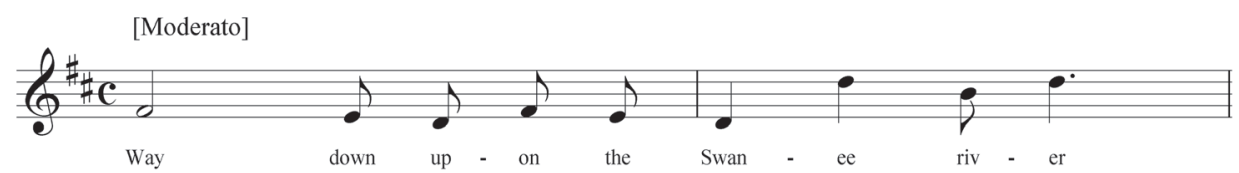

EXAMPLE 9 Dvořák, String Quintet in E-flat major, op. 97, opening melody (played by viola II)

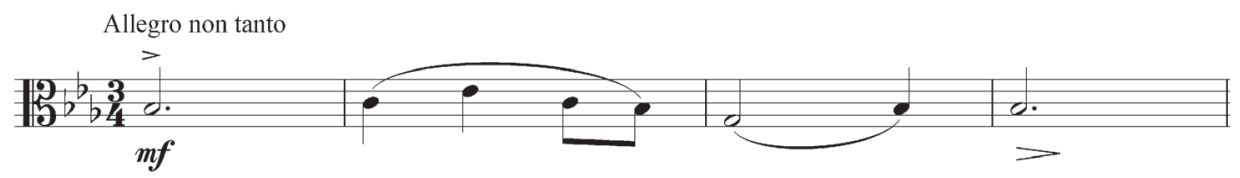

Mary and Sándor begin singing "Rose der Prairie" as a kind of game - yet by the end, the sweeping melody expresses their real passion. Kálmán's reconstructed American sound, with a Hungarian Gypsy flourish interjected, culminates in a perfect blend of musical material from the two cultures - just as the stiff European prince and the arrogant American heiress discover their true feelings for each other by "playing pretend."

\section{Happy end?}

I think this piece is not so bad at all, because we show people that all men are equal, and we should all mix, because through mixture one grows strong. And tolerance is part of that. [...] If someone knows only his own culture and no others, he is simply like someone in a tunnel who cannot look left or right. [...] I find that the Herzogin is ingenious [genial], maybe, because they all come 
together at the end, yes? and they find the path to each other [die finden zu einander]. (Mehrzad Montazeri)

The Krenek text he wrote himself, it's a vocabulary and jargon that people don't understand today, so the effect is like a museum - and for me, the music too. That doesn't get across any more today - and when it becomes museumish [museal], then I find theater so dangerous. [...] But the Kálmán - granted, it's from another genre, but I also find it much more real, closer to people - it has confusions and mixtures, and that makes the piece interesting. (Rudolf Berger)

It is remarkable how many windows this project has opened and how many unanswered questions it leaves in its wake. The contrasting attitudes and experiences of 1928 and 2004; the perspectives of critics, audience members, performers, directors; the associations of csárdás and Charleston; the class conflicts on both sides of the Atlantic that are somehow ignored in the libretto. Operetta as a reflection of social and political issues past and present - the Iraq War, the Kyoto Protocol, Nazism, ethnonationalism. Operetta as a blend of genres: song, dance, drama, film. People who think operetta should be bound to the past in style and performance, others who inject it with new ideas and materials. The critics' dislike, the audience's enthusiasm.

I believe that productions such as the 2004 Herzogin at the Volksoper strike a good balance between faithfulness and reinterpretation, between being original and respecting the original. For operetta to survive, it cannot rely on its previous public, but must also attract a new generation. This is more likely to happen when the pieces performed can be read as relevant to present-day life, and when productions draw on new artistic and technical developments since the work's premiere. The animated "Rose der Prairie" is a clear example - just barely possible in the 1920 s, the technology was easily available in 2004, and the result combined old and new in a satisfying way.

Most opera lovers have surely seen productions that went too far for their taste in reworking an original. In our conversation, Wilgenbus expressed his distaste for Regietheater productions based on flimsy evidence, in which the original is lost through the process of reinterpretation. Christoph Irrgeher's reference to the "paradox of a conservative Regietheater," though intended as a negative comment, accurately captured the reasons for Wilgenbus's mixed approach.

In Indonesia, the wayang kulit puppet plays retell age-old tales of Hindu mythology - but the ancient characters add lines that link those stories to contemporary social and political topics such as political corruption and child-sex tour- 
ism. ${ }^{34}$ This tradition, by emphasizing the connection of ancient tales to modern concerns, remains significant and viable, attracting large audiences. I believe that operetta productions that move in a similar direction have the greatest chance of keeping this entertaining and provocative genre on the stage for years to come and that would be a "Happy End" indeed. org/culture/ich/en/RL/wayang-puppet-theatre-00063 (accessed May 2016). 